\title{
Ciliary Body Leiomyoma
}

National Cancer Institute

\section{Source}

National Cancer Institute. Ciliary Body Leiomyoma. NCI Thesaurus. Code C4560.

A well-circumscribed benign smooth muscle neoplasm arising from the ciliary body of the

eye. It is characterized by the presence of spindle cells with cigar-shaped nuclei,

interlacing fascicles, and a whorled pattern. 